The Canadian Mineralogist

Vol. 43, pp. 689-694 (2005)

\title{
MILOTAITE, PdSbSe, A NEW PALLADIUM MINERAL SPECIES FROM PŘEDBOŘICE, CZECH REPUBLIC
}

\author{
WERNER H. PAAR ${ }^{\S}$ AND DAN TOPA \\ Department of Geography, Geology and Mineralogy, University of Salzburg, Hellbrunnerstr. 34, A-5020 Salzburg, Austria
}

EMIL MAKOVICKY

Geological Institute, University of Copenhagen, Østervoldgade 10, DK-1350 Copenhagen K, Denmark

FRANZ J. CULETTO

KELAG-Kärntner Elektrizitäts Aktiengesellschaft, Arnulfplatz 2, A-9021 Klagenfurt, Austria

\begin{abstract}
Milotaite, chemically PdSbSe, is a new palladium mineral species discovered in a low-temperature selenium-rich assemblage at Předbořice, Czech Republic. It was observed in only one polished section, where it occurs as rare subhedral grains not exceeding $25 \mu \mathrm{m}$ in size. It is embedded in eucairite and tiemannite, and randomly intergrown with bornite and digenite. The other associated phases are chrisstanleyite, fischesserite, native gold, silver-rich hakite, tyrrellite, clausthalite, chaméanite and uraninite. The gangue is calcite. The synthetic equivalent of PdSbSe is megascopically silvery grey in color, has a metallic luster and a grey streak. It is brittle with an uneven fracture; no cleavage or parting can be observed. Values of $\mathrm{VHN}_{100}$ (12 indentations on three grains of synthetic PdSbSe) range between 420 and 514, mean $465 \mathrm{~kg} / \mathrm{mm}^{2}$, which corresponds to a Mohs hardness of approximately $4 \frac{1}{2}$. In plane-polarized light, milotaite is white, isotropic and opaque, and lacks internal reflections. Reflectance data of both milotaite and its synthetic equivalent are provided. The average result of five electron-microprobe analyses of milotaite (two grains) is $\mathrm{Pd} 34.17, \mathrm{Cu} 0.78, \mathrm{Ag} 0.35, \mathrm{Sb} 38.03$, Se 26.38, total 99.71 wt.\%, corresponding to $\mathrm{Pd}_{0.98} \mathrm{Cu}_{0.04} \mathrm{Ag}_{0.01} \mathrm{Sb}_{0.95} \mathrm{Se}_{1.02}$; synthetic PdSbSe (17 analyses on 4 grains) gave Pd 34.46, Sb 38.86, Se 26.60, total 99.91 wt.\%, corresponding to $\mathrm{Pd}_{0.99} \mathrm{Sb}_{0.97} \mathrm{Se}_{1.04}$ (total atoms = 3). The synthetic PdSbSe has a cubic structure with $a$ 6.3181(5) $\AA, V 252.20(5) \AA^{3}$, space group $P 2{ }_{1} 3$, and $Z=4$. The calculated density is $8.09 \mathrm{~g} / \mathrm{cm}^{3}$. The crystal structure was solved using synthetic PdSbSe. The strongest eight lines in the calculated powder-diffraction pattern derived from the results of the crystal-structure refinement $[d$ in $\AA(I)(h k l)]$ are: $2.825(100)(201), 1.905(98)(311), 2.579(81)(211), 3.159(53)(200), 2.233(32)(220), 1.752(27)(320), 1.688(25)(312)$ and 1.378(18)(412). The mineral is named after Milota Makovicky, University of Copenhagen, for her outstanding investigations of sulfide and sulfarsenide systems with platinum-group elements.
\end{abstract}

Keywords: milotaite, new mineral species, platinum-group mineral, Pd-Sb selenide, electron-microprobe data, reflectance data, synthetic PdSbSe, X-ray-diffraction data, crystal structure, Předbořice, Czech Republic.

\section{SOMMAIRE}

La milotaïte, de formule idéale PdSbSe, est une nouvelle espèce minérale à palladium découverte dans un assemblage de basse température riche en sélénium à Předbořice, en République Tchèque. Nous l'avons trouvé dans une seule section polie, où elle se présente en rares grains sub-idiomorphes ne dépassant pas $25 \mu \mathrm{m}$ de taille. Elle est encastrée dans l'eucairite et la tiémannite, et en intercroissances aléatoires avec bornite et digénite. Lui sont aussi associés chrisstanleyite, fischesserite, or natif, hakite argentifère, tyrrellite, clausthalite, chaméanite et uraninite. La calcite forme la gangue. L'équivalent synthétique de PdSbSe a une couleur gris argenté en grains visibles, possède un éclat métallique et une rayure grise. C'est un minéral cassant, avec une fracture inégale. Nous n'avons pas vu de clivage ou de plan de séparation. Les valeurs de $\mathrm{VHN}_{100}$ (12 indentations faites sur trois grains de PdSbSe synthétique) varient entre 420 et 514 , pour une moyenne de $465 \mathrm{~kg} / \mathrm{mm}^{2}$, ce qui correspond à une dureté de Mohs d'environ 41/2. En lumière polarisée, la milotaïte est blanche, isotrope, opaque, et dépourvue de réflexions internes. Nous fournissons les données sur la réflectance de la milotaïte et de l'équivalent synthétique. Les résultats moyens de cinq analyses à

$\S \quad$ E-mail address: werner.paar@sbg.ac.at 
la microsonde électronique (deux grains) sont: $34.17, \mathrm{Cu} 0.78, \mathrm{Ag} 0.35, \mathrm{Sb} 38.03$, Se 26.38, pour un total de $99.71 \%$ (poids), ce qui correspond à $\mathrm{Pd}_{0.98} \mathrm{Cu}_{0.04} \mathrm{Ag}_{0.01} \mathrm{Sb}_{0.95} \mathrm{Se}_{1.02}$; le PdSbSe synthétique (17 analyses sur quatre grains) a donné $\mathrm{Pd} 34.46, \mathrm{Sb} 38.86$, Se 26.60, pour un total de $99.91 \%$, ce qui correspond à $\mathrm{Pd}_{0.99} \mathrm{Sb}_{0.97} \mathrm{Se}_{1.04}$ (nombre total d'atomes $=3$ ). Le PdSbSe synthétique possède une maille cubique, $a 6.3181(5) \AA, V 252.20(5) \AA^{3}$, groupe spatial $P 2{ }_{1} 3$, et $Z=4$. La densité calculée est $8.09 \mathrm{~g} / \mathrm{cm}^{3}$. Nous avons résolu la structure cristalline en utilisant le PdSbSe synthétique. Les huit raies les plus intenses du spectre de diffraction calculé, dérivé des résultats de l'ébauche de la structure $[d$ en $\AA(I)(h k l)]$, sont: $2.825(100)(201), 1.905(98)(311)$, $2.579(81)(211), 3.159(53)(200), 2.233(32)(220), 1.752(27)(320), 1.688(25)(312)$ et 1.378(18)(412). Le nom honore Milota Makovicky, Université de Copenhague, en raison de ses études remarquables de systèmes sulfurés et sulfarséniés contenant les éléments du groupe du platine.

(Traduit par la Rédaction)

Mots-clés: milotaïte, nouvelle espèce minérale, minéral du groupe du platine, séléniure de $\mathrm{Pd}-\mathrm{Sb}$, données de microsonde électronique, données de réflectance, PdSbSe synthétique, diffraction données, structure cristalline, Předbořice, République Tchèque.

\section{INTRODUCTION}

In 1989, Z. Johan described an example of low-temperature selenide-bearing uranium mineralization from Předbořice, Czech Republic, developed in carbonate veins cross-cutting metamorphic rocks of the "Krásná Hora - Sedlčany islet" in central Bohemia. The selenide assemblage is composed of (in order of crystallization) ferroselite, eskebornite, bukovite, berzelianite, umangite, clausthalite, permingeatite, hakite, eucairite, naumannite, fischesserite, tiemannite, and is accompanied by native gold and uraninite (Johan 1989). Selenium-bearing merenskyite, $\mathrm{Pd}(\mathrm{Te}, \mathrm{Se})_{2}$, closely associated with clausthalite, is the only mineral of palladium recognized by Dr. Johan.

During a systematic study of polished sections prepared of material from Předbořice, two further platinumgroup minerals were observed: chrisstanleyite (Paar et al. 1998) and yet another palladium-dominant phase, the newly recognized analogue of synthetic PdSbSe. The new $\mathrm{Pd}-\mathrm{Sb}$ selenide is named after Milota Makovicky (b. 1941), Geological Institute (University of Copenhagen), for her outstanding contributions to the study of the sulfide and sulfarsenide systems with platinum-group elements. The mineral and the name have been approved by the Commission on New Minerals and Mineral Names, IMA (2003-056). The holotype material (one polished section) is deposited at the Department of Geography, Geology and Mineralogy, Division of Mineralogy and Material Sciences (Mineralogical Museum), Salzburg, Austria, and registered under catalogue number 14935 .

\section{The Selenide Association}

The holotype specimen that contains milotaite measures $3 \times 2.5 \times 0.5 \mathrm{~cm}$ and was purchased at a mineral fair in 2001 from a Czech mineral dealer. The specimen was offered as a polished section and labeled "Aghakite" from Předbořice, Czech Republic. It was cut into three thin slices, each between 1 to $2 \mathrm{~mm}$ thick, of which three polished sections were made. Only one contains the new palladium mineral.

The dominant mineral in all sections is uraninite, in botryoidal and reniform masses embedded in a calcite matrix that has inclusions of fragmented and reddish to brownish country-rock with finely dispersed tablets of hematite. The selenide association forms a network in the calcite and together with sulfide minerals (bornite, chalcopyrite, selenian digenite) heals fractures in the uraninite. The two Pd-bearing minerals milotaite and chrisstanleyite are accompanied by abundant clausthalite, tiemannite, argentian hakite, eucairite, tyrrellite and trace amounts of chaméanite, (?) giraudite (Fig. 1ad) and klockmannite. Rare specks of native gold varying in size from a few $\mu \mathrm{m}$ up to less than $50 \mu \mathrm{m}$ are embedded in the calcite.

Chrisstanleyite is associated with clausthalite, eucairite and a bornite-chalcopyrite intergrowth (Fig. 1b). It corresponds chemically to the Ag-dominant endmember of the series $\mathrm{Ag}_{2} \mathrm{Pd}_{3} \mathrm{Se}_{4}-\mathrm{Cu}_{2} \mathrm{Pd}_{3} \mathrm{~S}_{4}$, described by Paar et al. (1998) as a new mineral species from Hope's Nose, Devon, United Kingdom.

Tyrrellite and tyrrellite-related phases can be observed as euhedral to subhedral crystals in a selenide matrix. The crystals commonly are fractured and replaced by eucairite, tiemannite and selenian digenite. A preliminary electron-microprobe analysis indicates significant variations in the proportions of $\mathrm{Ni}, \mathrm{Co}$, and $\mathrm{Cu}$, which apparently are responsible for the different colors of these varieties in reflected light (Fig. 1c). Tyrrellite (ty 2 in Fig. 1c) is semiquantitatively characterized by $\mathrm{Co}>\mathrm{Ni}>\mathrm{Cu}$, whereas the tyrrellite-related phases have $\mathrm{Ni}>\mathrm{Co}>\mathrm{Cu}$ (ty 1 ) and $\mathrm{Cu}>\mathrm{Co}, \mathrm{Ni}$ (ty 3 ), respectively. Similar variations in the composition of tyrrellite have been reported previously from the uranium deposits of western Moravia (Kvaček 1979). A detailed investigation of the composition of tyrrellite from different locations worldwide is currently in progress. 

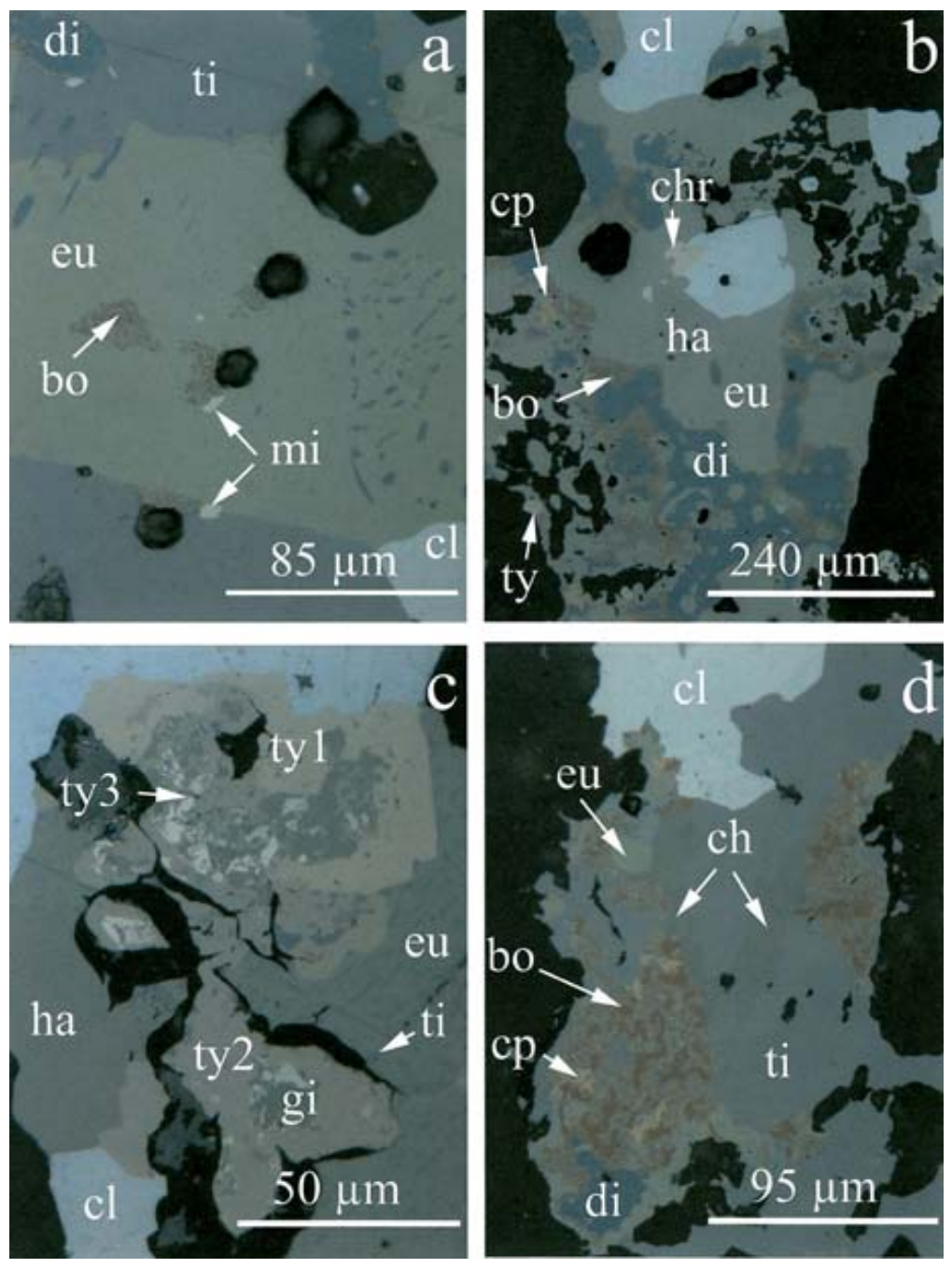

FIG. 1. a-d. Milotaite (mi) and associated minerals from Předbořice, Czech Republic. The abbreviations are: bo (bornite), ch (chaméanite), chr (chrisstanleyite), cl (clausthalite), cp (chalcopyrite), di (selenian digenite), eu (eucairite), gi (giraudite), ha (hakite), ti (tiemannite) and ty (tyrrellite). a) Milotaite occurs as subhedral, minute inclusions in eucairite-tiemannite (s. 02/66). b) Chrisstanleyite is present as a single grain intergrown with clausthalite and eucairite. Note the graphic intergrowth of bornite - chalcopyrite selenian digenite replacing the selenide assemblage (s. 02/66). c) Tyrrellite (ty 2) and tyrrellite-related phases (ty 1,3) can be observed in subhedral (ty 1,2) and anhedral (ty 3 ) crystals, which are chemically different; ty 3 is closely associated with (?) giraudite (gi) (s. 02/66). d) Chaméanite remains as elongate relics after replacement in a matrix of tiemannite. The graphic texture involves an intergrowth of bornite - chalcopyrite selenian digenite and eucairite (s. 03/05).

Chaméanite occurs as rare relics of a replacement process in tiemannite (Fig. 1d) and is associated with hakite and clausthalite.

Of particular interest are oriented and minute inclusions of selenian digenite in eucairite and tiemannite, and of tiemannite inclusions in eucairite (Fig. 1c). A graphic intergrowth of bornite - chalcopyrite - selenian digenite - eucairite are common in a matrix of eucairite, where it forms irregularly shaped "islands". 


\section{Milotaite}

\section{General appearance and physical properties}

Milotaite occurs as subhedral grains (Fig. 1a) not exceeding $25 \mu \mathrm{m}$ in diameter, embedded in eucairite and tiemannite, and randomly intergrown with a graphic intergrowth of bornite and selenian digenite. Synthetic milotaite has a silvery grey megascopic color, a metallic luster and is opaque. No cleavage or parting was observed; the mineral is brittle, with an uneven fracture.

The $\mathrm{VHN}_{100}$ (12 indentations on three grains) was determined on synthetic PdSbSe and ranges between 420 and 514 (mean 465) kg/mm². The Mohs hardness is approximately $4 \frac{1}{2}$ using the mean $\mathrm{VHN}_{100}$ value and the equation of Young \& Millman (1964).

The density, calculated on the basis of the empirical formula, is $8.09 \mathrm{~g} / \mathrm{cm}^{3}$. The measured density of synthetic PdSbSe using two different fragments (20.5 and $25.04 \mathrm{mg}$ ) varies between 7.95 and $8.23 \mathrm{~g} / \mathrm{cm}^{3}$, a variability caused by inclusions of $\mathrm{Sb}_{2} \mathrm{Se}_{3}$, native palladium and another compound, which could not be separated.

\section{Optical properties}

In plane-polarized light $(\sim 3200 \mathrm{~K})$, milotaite and synthetic PdSbSe are white, isotropic, and lack internal reflections. Reflectance measurements were made for both materials within the visible spectrum (400-700 nm) using a Leitz MPV-SP microscope-spectrophotometer. A WTiC reflectance standard (Zeiss 314) was used as a reference for the air measurements. These were performed with $\times 50$ (milotaite) and $\times 20$ (synthetic $\mathrm{PdSbSe}$ ) objectives, the numerical apertures of which were confined to 0.85 and 0.40 , respectively (Table 1 ). A flat reflection curve, with slightly raised $\mathrm{R}$ values at both the $400 \mathrm{~nm}$ and $700 \mathrm{~nm}$ ends, corresponds well to the white color of the mineral. Considering the limitations stemming from the size of the natural grains, the correspondence of the two curves (milotaite and synthetic PdSbSe) is very satisfactory.

TABLE 1. REFLECTANCE VALUES FOR NATURAL AND SYNTHETIC MILOTAITE

\begin{tabular}{cccccc}
\hline $\begin{array}{c}\lambda \\
\mathrm{nm}\end{array}$ & $\begin{array}{c}\text { natural } \\
\mathrm{R} \%\end{array}$ & $\begin{array}{c}\text { synthetic } \\
\mathrm{R} \%\end{array}$ & $\begin{array}{c}\lambda \\
\mathrm{nm}\end{array}$ & $\begin{array}{c}\text { natural } \\
\mathrm{R} \%\end{array}$ & $\begin{array}{c}\text { synthetic } \\
\mathrm{R} \%\end{array}$ \\
\hline & & & & & \\
400 & 51.8 & 53.8 & 560 & 47.6 & 47.0 \\
420 & 51.9 & 53.0 & 580 & 47.6 & 47.0 \\
440 & 51.9 & 51.3 & $\mathbf{5 8 9}$ & 47.6 & $\mathbf{4 7 . 0}$ \\
460 & 49.6 & 48.9 & 600 & 47.6 & 47.0 \\
$\mathbf{4 7 0}$ & $\mathbf{4 8 . 6}$ & $\mathbf{4 8 . 0}$ & 620 & 47.9 & 47.4 \\
480 & 48.2 & 47.6 & 640 & 48.7 & 47.8 \\
500 & 47.5 & 47.2 & $\mathbf{6 5 0}$ & $\mathbf{4 9 . 0}$ & $\mathbf{4 8 . 2}$ \\
520 & 47.3 & 47.1 & 660 & 49.4 & 48.8 \\
540 & 47.5 & 47.2 & 680 & 50.1 & 49.5 \\
$\mathbf{5 4 6}$ & $\mathbf{4 7 . 5}$ & $\mathbf{4 7 . 1}$ & 700 & 50.5 & 49.9 \\
& & & & &
\end{tabular}

\section{Chemical data}

Chemical analyses were performed in the wavelength-dispersion mode using JEOL JXA-8600 electron microprobe equipped with a LINK-eXL system. Acceleration voltage was $25 \mathrm{kV}$, and the beam current, 35 $\mathrm{nA}$, with $\mathrm{ZAF}-4$ correction procedures used on-line. No other elements with $Z>11$ were detected (Table 2). The empirical formula for $\mathrm{Z}=4$ is $\mathrm{Pd}_{0.98} \mathrm{Cu}_{0.04} \mathrm{Ag}_{0.01}$ $\mathrm{Sb}_{0.95} \mathrm{Se}_{1.02}$ for milotaite, and $\mathrm{Pd}_{0.99} \mathrm{Sb}_{0.97} \mathrm{Se}_{1.04}$ for synthetic PdSbSe. The empirical formula matches very well the model formula, PdSbSe, obtained from the structure refinement.

Multiphase samples in the system $\mathrm{Pd}-\mathrm{Sb}-\mathrm{Se}$, with a $\mathrm{Pd}_{1.0} \mathrm{Sb}_{1.0} \mathrm{Se}_{1.0}$ (initial) chemical composition, were made by partial-melt synthesis, starting from element mixtures (Pd foil, Se shot, Sb powder). A sealed ampulla technique $\left(0.1\right.$ bar $\mathrm{N}_{2}, 4 \mathrm{~K} \cdot \mathrm{min}^{-1}$ heating rate, $760^{\circ} \mathrm{C}$ maximum temperature for 10 minutes, 20 hours cool-down) was used. The resulting product is mainly composed of recrystallized $\mathrm{PdSbSe}(>95 \%)$ forming grain aggregates with very minor other compounds $\left(<5 \% ; \sim \mathrm{Pd}_{5} \mathrm{Sb}_{2} \mathrm{Se}_{8}, \sim \mathrm{Pd}_{8} \mathrm{Sb}_{3}\right)$ located as irregular and thin films at grain boundaries.

\section{Crystallographic data}

The small grains of natural material embedded intimately in other selenides and sulfides prevented its extraction and investigation by means of X-ray diffraction. Therefore, the relevant crystallographic and structural investigations were performed on synthetic PdSbSe.

In the single-crystal study, we employed a Bruker P4 single-crystal diffractometer equipped with an CCD area-detector system (Bruker AXS 1997, 1998). Unitcell parameters were refined from single-crystal data, and the crystal structure was solved to an $R_{1}$ index of

\begin{tabular}{|c|c|c|c|c|}
\hline \multirow[t]{2}{*}{ Constituent } & \multicolumn{2}{|c|}{ Range } & \multirow{2}{*}{$\begin{array}{c}\text { Std. dev. } \\
\sigma_{n}\end{array}$} & \multirow[t]{2}{*}{ Probe standard } \\
\hline & Min & $\operatorname{Max}$ & & \\
\hline
\end{tabular}

\begin{tabular}{|c|c|c|c|c|c|}
\hline \multicolumn{6}{|c|}{ a) Natural material: 5 analyses on two grains } \\
\hline Pd wt. \% & 34.17 & 33.89 & 34.43 & 0.22 & metal (synthetic) $\mathrm{Pd} L \alpha$ \\
\hline $\mathrm{Cu}$ & 0.78 & 0.69 & 0.88 & 0.08 & umangite (natural) $\mathrm{CuKa}$ \\
\hline $\mathrm{Ag}$ & 0.35 & 0.26 & 0.50 & 0.11 & metal (synthetic) AgLa \\
\hline $\mathrm{Sb}$ & 38.03 & 37.96 & 38.16 & 0.09 & stibnite (natural) $\mathrm{Sb} L a$ \\
\hline $\mathrm{Se}$ & 26.38 & 26.27 & 26.49 & 0.09 & umangite (natural) $\mathrm{Se} K \alpha$ \\
\hline Total & 99.71 & - & - & 0.27 & \\
\hline \multicolumn{6}{|c|}{ b) Synthetic material: 17 analyses on four grains } \\
\hline $\mathrm{Pd}$ & 34.46 & 34.04 & $35.0 \mathrm{l}$ & 0.29 & metal (synthetic) $\mathrm{Pd} L a$ \\
\hline $\mathrm{Sb}$ & 38.86 & 38.01 & 39.31 & 0.28 & $\mathrm{Sb}_{2} \mathrm{Se}_{3}$ (synthetic) $\mathrm{Sb} L \mathrm{a}$ \\
\hline $\mathrm{Se}$ & 26.60 & 26.14 & 27.01 & 0.23 & $\mathrm{Sb}_{2} \mathrm{Se}_{3}$ (synthetic) $\mathrm{Se} K \alpha$ \\
\hline Total & 99.91 & - & - & 0.36 & \\
\hline
\end{tabular}


TABLE 3. ATOM POSITIONS AND DISPLACEMENT PARAMETERS $\left(\AA^{2}\right)$ FOR SYNTHETIC MILOTAITE

\begin{tabular}{|c|c|c|c|c|c|c|c|c|c|c|}
\hline АTOM & $x$ & $y$ & $z$ & Ueq & $U_{1 I}$ & $U_{22}$ & $U_{33}$ & $U_{23}$ & $U_{13}$ & $U_{12}$ \\
\hline $\mathrm{Sb}$ & $0.12677(5)$ & $0.12677(5)$ & $0.12677(5)$ & $0.0096(2)$ & $0.0096(2)$ & $0.0096(2)$ & $0.0096(2)$ & $0.0011(1)$ & $0.0011(1)$ & $0.0011(1)$ \\
\hline $\mathrm{Se}$ & $0.63232(7)$ & $0.86768(7)$ & $0.13232(7)$ & $0.0104(2)$ & $0.0104(2)$ & $0.0104(2)$ & $0.0104(2)$ & $-0.0006(2)$ & $0.0006(2)$ & $-0.0006(2)$ \\
\hline $\mathrm{Pd}$ & $0.25390(6)$ & $0.74610(6)$ & $0.24610(6)$ & $0.0088(2)$ & $0.0088(2)$ & $0.0088(2)$ & $0.0088(2)$ & $0.0001(1)$ & $-0.0001(1)$ & $-0.0001(1)$ \\
\hline
\end{tabular}

The unit-cell edge $a$ is $6.3181(5) \AA$, and the space group of milotaite is $P 2,3$.

$1.84 \%$ for 248 observed $\left[\mathrm{F}_{0}>4 \sigma\left(\mathrm{F}_{0}\right)\right]$ unique reflections, corrected for absorption with an empirical (ellipsoidal function) correction. The cubic structure has space group $P 2{ }_{1} 3, a 6.3181(5) \AA$, unit-cell volume 252.20(5) $\AA^{3}, Z=4$ for PdSbSe. The unit cell, space group, atom positions and anisotropic structure-parameter (Table 3) are in good agreement with data published by Foecker \& Jeitscho (2001). The powder-diffraction data were derived from the results of the crystal-structure refinement. The program used was Powder Cell 2.3 (Kraus \& Nolze 1999) in Debye-Scherrer configuration, for $\mathrm{Cu} K \alpha_{1}$ radiation $(\lambda 1.540598 \AA)$, fixed slit, no anomalous dispersion, full site-occupancies and anisotropic displacement factors (Table 4).

The crystal structure of milotaite (and synthetic $\mathrm{PdSbSe}$ ) contains octahedrally coordinated palladium, with three $\mathrm{Sb}$ and three $\mathrm{Se}$ atoms as ligands. All anions form covalent $\mathrm{Sb}-\mathrm{Se}$ pairs, with the length of the covalent bond equal to $2.636 \AA$, to be compared with the Pd-Sb bonds (2.645 $\AA$ ) and Pd-Se bonds (2.612 $\AA$ ). Antimony and selenium are fully ordered, and milotaite belongs to the ullmannite (i.e., $P 2{ }_{1} 3$ ) subgroup with ordered anions (Pratt \& Bayliss 1980) of the gersdorffite group $\left(M X_{1} X_{2}\right.$ where $X_{1}=\mathrm{S}, \mathrm{Se}, \mathrm{Te}$, and $X_{2}=\mathrm{As}, \mathrm{Sb}$, $\mathrm{Bi})$, all these being various homeotypes of pyrite ( $\mathrm{Pa} 3$ ). The most closely related species are michenerite PdBiTe (Cabri et al. 1973, Childs \& Hall 1973) and testibiopalladite PdSbTe (Kim \& Chao 1991). For both these phases, the authors had to involve synthetic material in the definition of mineral species because of their scarcity, a situation analogous to that in the present study.

The crystal structure of PdSbSe is a homeotype of the structure of pyrite, $\mathrm{FeS}_{2}$, (space group Pa3) (Brostigen \& Kjekshus 1969) and an isotype of the cubic ordered structure of gersdorffite, NiAsS (space group $P 2{ }_{1} 3$ ) (Steger et al. 1974). Basic elements of the structure are coordination octahedra $\mathrm{PdSb}_{3} \mathrm{Se}_{3}$ and covalent pairs $\mathrm{Sb}-\mathrm{Se}$. The bond lengths are $d(\mathrm{Pd}-\mathrm{Sb})=$ 2.6454(3) $\AA, d(\mathrm{Pd}-\mathrm{Se})=2.6121(4) \AA$, and the covalent bond $d(\mathrm{Sb}-\mathrm{Se})=2.6363(9) \AA$. Intraoctahedral angles are the triplets $\mathrm{Sb}-\mathrm{Pd}-\mathrm{Sb}=93.99(2)^{\circ}, \mathrm{Se}-\mathrm{Pd}-\mathrm{Se}=$ $95.64(2)^{\circ}$, and $\mathrm{Sb}-\mathrm{Pd}-\mathrm{Se}=84.26(1)^{\circ}$ and $86.11(2)^{\circ}$,

\begin{tabular}{|c|c|c|c|c|c|c|c|}
\hline$I$ & $d$ & $h$ & $k \quad l$ & $I$ & $d$ & $h$ & $k$ \\
\hline 6 & 4.46694 & & 0 & 27 & 1.75208 & & 20 \\
\hline 10 & 3.64724 & ] & 1 & 1 & 1.75208 & & 02 \\
\hline 53 & 3.15860 & 20 & 0 & 17 & 1.68834 & 3 & 2 \\
\hline 100 & 2.82514 & 2 & 1 & 25 & 1.68834 & & 12 \\
\hline 6 & 2.82514 & 2 & 0 & 3 & 1.57930 & 4 & 6) \\
\hline 81 & 2.57899 & 2 & 1 & 3 & 1.44927 & & 3 \\
\hline 32 & 2.23347 & 2 & 0 & 5 & 1.41257 & & 6) \\
\hline 1 & 1.99767 & 3 & 0 & 5 & 1.41257 & & 21 \\
\hline 98 & 1.90471 & 3 & 1 & 18 & 1.37853 & 4 & 12 \\
\hline 12 & 1.82362 & 2 & 2 & 8 & 1.34683 & & 32 \\
\hline
\end{tabular}

respectively. The $\mathrm{Sb}-\mathrm{Pd}-\mathrm{Se}$ angles across the octahedron center are $178.25(2)^{\circ}$. There are three Pd octahedra sharing every anion. The $\mathrm{Pd}-\mathrm{Sb}-\mathrm{Pd}$ angle is equal to $116.655(7)^{\circ}$, whereas the $\mathrm{Pd}-\mathrm{Se}-\mathrm{Pd}$ angle is 116.11(1) ${ }^{\circ}$. The $\mathrm{Pd}-\mathrm{Sb}-\mathrm{Se}$ angle in the $\mathrm{Pd}_{3} \mathrm{Se}$ tetrahedron of $\mathrm{Sb}$ and the $\mathrm{Pd}-\mathrm{Se}-\mathrm{Sb}$ angle in the $\mathrm{Pd}_{3} \mathrm{Sb}$ coordination tetrahedron of Se are very different from these values, $100.67(1)^{\circ}$ and $101.52(2)^{\circ}$, respectively.

In the homeotype $\mathrm{FeS}_{2}(\mathrm{~Pa} 3)$, the intraoctahedral distance $d(\mathrm{Fe}-\mathrm{S})=2.26 \AA$ for all six bonds and $d(\mathrm{~S}-\mathrm{S})$ $=2.18 \AA$, distinctly shorter than the $\mathrm{Fe}-\mathrm{S}$ distance (Brostigen et al. 1969). In PdBiTe $\left(P 2_{1} 3\right)$ with $a 6.642 \AA$, $d(\mathrm{Pd}-\mathrm{Bi})=2.77 \AA$ and $d(\mathrm{Pd}-\mathrm{Te})=2.72 \AA$, whereas $d(\mathrm{Te}-\mathrm{Bi})$ is much longer, $2.98 \AA$ (Childs \& Hall 1973). NiAsS $\left(P 2{ }_{1} 3, a 5.685 \AA\right)$ has $d(\mathrm{Ni}-\mathrm{S})=2.34 \AA$, $d(\mathrm{Ni}-$ $\mathrm{As})=2.42 \AA$, whereas the covalent pair has $d(\mathrm{~S}-\mathrm{As})=$ $2.25 \AA$ (Steger et al. 1974), a situation similar to that in pyrite, although complicated by a lower symmetry. In marcasite, $d(\mathrm{Fe}-\mathrm{S})$ is in the range $2.24-2.25 \AA$, and $d(\mathrm{~S}-$ S) is $2.22 \AA$ (Brostigen et al. 1970). Therefore, the ratio $d(M-x) / d\left(x_{1}-x_{2}\right)$ in marcasite is closer to that in $\mathrm{PdSbSe}$ than the corresponding ratio in pyrite. This fact, together with a wide variety of values of this ratio in the compounds above quoted, suggest that the ratio $d(M-$ $x) / d\left(x_{1}-x_{2}\right)$ is not a determining factor whether the compound belongs among the pyrite or the marcasite homeotypes. 


\section{ACKNOWLEDGEMENTS}

The authors are most grateful to Hubert Putz for the photographs, to Georg Zagler for the reflectance measurements, and to Margit Ebner, who typed the manuscript. Comments of Chris Stanley, Nigel Cook and an anonymous referee are appreciated. They helped to improve the manuscript. The editorial care of Robert F. Martin is especially acknowledged. This study was supported by the Carlsberg Fund, Program No. ANS/1185/ 10.

\section{REFERENCES}

Brostigen, G. \& KJeKshus, A. (1969): Redetermined crystal structure of $\mathrm{FeS}_{2}$ (pyrite). Acta Chem. Scand. 23, 21862188.

\section{$\&$}

(1970): Compounds with the marcasite type crystal structure. V. The crystal structures of $\mathrm{FeS}_{2}$, $\mathrm{FeTe}_{2}$, and $\mathrm{CoTe}_{2}$. Acta Chem. Scand. 24, 1925-1940.

BRUKER AXS (1997): SHELXTL, V. 5.1, Bruker AXS, Inc., Madison, Wisconsin 53719, USA

BRUKER AXS (1998): SMART, V. 5.0, Bruker AXS, Inc., Madison, Wisconsin 53719, USA

CABRI, L.J., HARRIS, D.C. \& GAIT, R.I. (1973): Michenerite (PdBiTe) redefined and froodite $\left(\mathrm{PdBi}_{2}\right)$ confirmed from the Sudbury area. Can. Mineral. 11, 903-912.

ChILDS, D.J. \& HALL, S.R. (1973): The crystal structure of michenerite, PdBiTe. Can. Mineral. 12, 61-65.

FoECKER, A.J. \& JEITSCHKo, W. (2001): The atomic order of the pnictogen and chalcogen atoms in equiatomic ternary compounds $T P n C h(T=\mathrm{Ni}, \mathrm{Pd} ; P n=\mathrm{P}, \mathrm{As}, \mathrm{Sb} ; C h=\mathrm{S}, \mathrm{Se}$, Te). J. Solid State Chem. 162, 69-78.

JoHAN, Z. (1989): Merenskyite, $\mathrm{Pd}(\mathrm{Te}, \mathrm{Se})_{2}$, and the low-temperature selenide association from the Předbořice uranium deposit, Czechoslovakia. Neues Jahrb. Mineral., Monatsh., 179-191.

KIM, Won-SA \& ChaO, G.Y. (1991): Phase relation in the system Pd-Sb-Te. Can. Mineral. 29, 401-409.

Kraus, W. \& Nolze, G. (1999): Powder Cell for Windows, version 2.3. BAM, Berlin, Germany.

KvačEK, M. (1979): Selenides from the deposits of western Moravia, Czechoslovakia 2. Acta Universitatis CarolinaeGeologica 1-2, 15-38.

PAAR, W.H., Roberts, A.C., Criddle, A.J. \& Topa, D. (1998): A new mineral, chrisstanleyite, $\mathrm{Ag}_{2} \mathrm{Pd}_{3} \mathrm{Se}_{4}$, from Hope's Nose, Torquay, Devon, England. Mineral. Mag. 62, 257264.

PRATT, J.L. \& BAYLISS, P. (1980): Crystal structure refinement of a cobaltian ullmannite. Am. Mineral. 65, 154-156.

Steger, J.J., Nahigian, H., ARnotT, R.J. \& Wold, A. (1974): Preparation and characterization of the solid solution series $\mathrm{Co}_{1-x} \mathrm{Ni}_{x} \mathrm{AsS}(0 \leq x \leq 1)$. J. Solid State Chem. 11, 53-59.

Young, B.B. \& Millman, A.P. (1964): Microhardness and deformation characteristics of ore minerals. Inst. Mining Metall. Trans. 73, 437-466.

Received September 29, 2004, revised manuscript accepted December 9, 2004. 